\title{
RICHARD LEVINS (1930-2016)
}

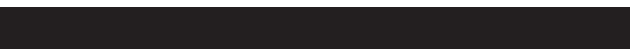

Kuinka pitkä matka on Puerto Ricosta Havannaan? Riippuu siitä, mitä reittiä matkustaa. Richard Levins toteutti perheineen tuon matkan lentäen reitillä Puerto Rico - Mexico City-Montreal - Praha-Madrid - Havanna. Vuosi oli 1965 (mikäli oikein muistan hänen mainintansa). Tuohon aikaan, muutama vuosi Kuuban vallankumouksen jälkeen, suoraa pääsyä Puerto Ricosta (joka oli ja on Yhdysvaltojen alusmaa) Kuubaan ei ollut. Levins naureskeli tapauksesta kertoessaan, että FBI/ CIA kadotti hänen perheensä jäljet Madridiin; tämä oli käynyt ilmi papereista, joita hän sai kauan jälkeenpäin käsiinsä Freedom of Information Act-säädösten nojalla.

Levins oli yksi 1960-luvulta alkaen kehitetyn modernin, matemaattisia malleja hyödyntävän populaatioekologian keskeisistä hahmoista. ${ }^{1}$ Lisäksi Levins oli vakaumuksellinen marxilainen. Hän kasvoi kommunistiperheessä Brooklynissä, hänen isovanhempansa olivat juutalais-immigrantteja Ukrainasta. Levins vitsaili joskus, että hänen asuinalueensa vaalipiirissä Yhdysvaltojen kommunistipuolueen ehdokkaat saivat yleensä kuusi ääntä, jotka olivat peräisin samasta talosta, mutta kerran ääniä tuli vain viisi, kun hänen isoisänsä äänesti Rooseveltia.

Levins kävi Helsingissä pitämässä esitelmän Tutkijaliiton kollokviossa Humanity and Nature marraskuussa 1982. Olin silloin vastuussa kollokvion kansainvälisten vieraiden kutsumisesta. Olin kuullut jostakin, muistaakseni kollegaltani Olli Järviseltä, että Levins voisi olla kiinnostunut marxilaisuuden ja ympäristökysymysten yhteyksistä; en tiedä, millaisten tietojen perusteella hän oli tähän käsitykseen päätynyt. Rohkaistuin kirjoittamaan kutsun. Levinsin vastauskirje tuli muutamaa viikkoa myöhemmin (vuonna 1982 käytiin kirjeenvaihtoa!), ja hän totesi siinä yksikantaan, että jos kysymys olisi tavanomaisesta ammatillisesta kokouksesta, hän ei epäröisi kieltäytyä, mutta järjestävä organisaatio on niin kiinnostava, että hän haluaa ehdottomasti tulla.

Levins oli vakuuttavan suorasanainen puhuja; on joskus sanottu, että hänen puheensa yksiköitä olivat kokonaiset kappaleet ("paragraphs") - eli ehyet argumentit. ${ }^{2}$ Hänen Helsingin vierailustaan sai alkunsa yhteistyömme, jonka tuloksena syntyi kirja Humanity and $\mathrm{Na}$ ture (Pluto Press, 1992; suomennos: Ekologian ulottuvuudet, Vastapaino 1993). Lisäksi Levins ystävystyi T\&E:n kanssa. ${ }^{3}$

Mutta entäpä marxilaisuus ja ympäristökysymys - sekä biologia yleisemminkin? Tuonaikaisia näkemyksiään Levins esitteli T\&E:n julkaisemassa haastattelussa. Friedrich Engels ja dialektiikka olivat hänen marxilaisuutensa olennainen virike. Tämä kuulostaa ehkä dogmaattiselta, mutta Levins oli kaikkea muuta. Pikemminkin hän oli mitä tyypillisin amerikkalaisen pragmaattisuuden edustaja: Olennaista on se, millaisiksi ongelmat määritellään. Määrittelyyn tulee sisällyttää se, mikä on merkityksellistä, ja muu tulee jättää määrittelyn ulkopuolelle. Hän omaksui hyvin käytännöllisen näkökulman mallien käyttöön ekologisen sekä erityisesti ekososiaalisen tutkimuksen välineenä. ${ }^{4}$

Dialektiikka levinsiläisittäin korostaa ongelmien kompleksisuutta ja mitä erilaisimpien seikkojen kytkeytymistä toisiinsa. Vakiintuneet tieteenalat antavat tärkeiden tutkimusongelmien määrittelemiseksi yhtä kehnon ohjenuoran kuin hallinnon sektorien jako antaa poliittisten ongelmien märitttelemiseksi. Esimerkiksi työpaikalla koettua stressiä kuvaavaan malliin voi mainiosti liittää vaikuttaviksi muuttujiksi fysiologisia tekijöitä kuten adrenaliinin, 
verensokerin, insuliinin ja metabolian tason sekä sosiaalisina tekijöinä ahdistuksen tunteen, ammattiosaston tuen ja esimiehen painostuksen. Kvantitatiivisia ennusteita tällaisesta mallista ei voi johtaa, mutta se ei ole tarkoituskaan. Levinsin dialektiikassa olennaista on selvittää ongelmien laadullisia piirteitä ja erilaisten tekijöiden riippuvuussuhteita.

Levins kokosi evoluutiobiologian ja marxilaisuuden suhteita koskevat näkemyksensä kahteen yhdessä pitkäaikaisen kollegansa Richard Lewontinin kanssa julkaisemaansa kirjaan: The Dialectical Biologist (Harvard UP, 1985) ja Biology Under the Influence. Dialectical Essays on Ecology, Agriculture, and Health

\section{VIITTEET}

1. "Moderni populaatioekologia" eli matemaattisten mallien soveltaminen populaatioiden dynamiikan selvittämiseen sai alkunsa 1920-luvulla (Alfred Lotka, Vito Volterra), mutta varsinaisesti malleja ryhdyttiin systemaattisesti kehittämään 1960-luvulta lähtien. Levins oli yksi perinteen varhaisista kehittäjistä; hänen merkittävin panoksensa oli teos Evolution in Changing Environments: Some Theoretical Explorations (Princeton UP, 1968).

2. Huomautus sisältyy teokseen Callebaut, Werner (toim.). Taking the Naturalistic Turn, Or How Real
(Montly Review Press, 2007). ${ }^{5}$ Teokset kokoavat yhteen näiden kahden Dick L.:n aiemmin julkaistuja esseitä, osa niistä yhteisiä, osa jomman kumman erikseen julkaisemia. Lewontin on ollut heistä aktiivisempi julkisessa keskustelussa biologisen determinismin kriitikkona esimerkiksi Nerw York Review of Books -lehden säännöllisenä avustajana. Levins suuntasi aktivisminsa pikemmin Yhdysvaltojen vasemmistolaisiin järjestöihin ja liikkeisiin; Science for the People -järjestö oli yksi hänen tukipisteistään, ja lisäksi hän jatkoi koko ikänsä 60-luvulla alkanutta yhteistyötä kuubalaisten ekologien kanssa muun muassa biologisen tuholaistorjunnan menetelmien kehittämiseksi.

- YRJÖ HAILA

Philosophy of Science Is Done (University of Chicago Press, 1993).

3. T\&E (1/1983) julkaisi Levinsin haastattelun "Marxilaisena biologina Yhdysvalloissa. Richard Levinsin haastattelu".

4. Mallien käytön "pragmatiikkaa" koskeva runsaasti siteerattu Levinsin artikkeli on "The strategy of model building in population biology" (American Scientist 54(4), 1966).

5. Jälkimmäinen teos sisältää joukon Levinsin ekologiaa ja evoluutiota koskevan dialektisen näkemyksen avainkirjoituksia. 